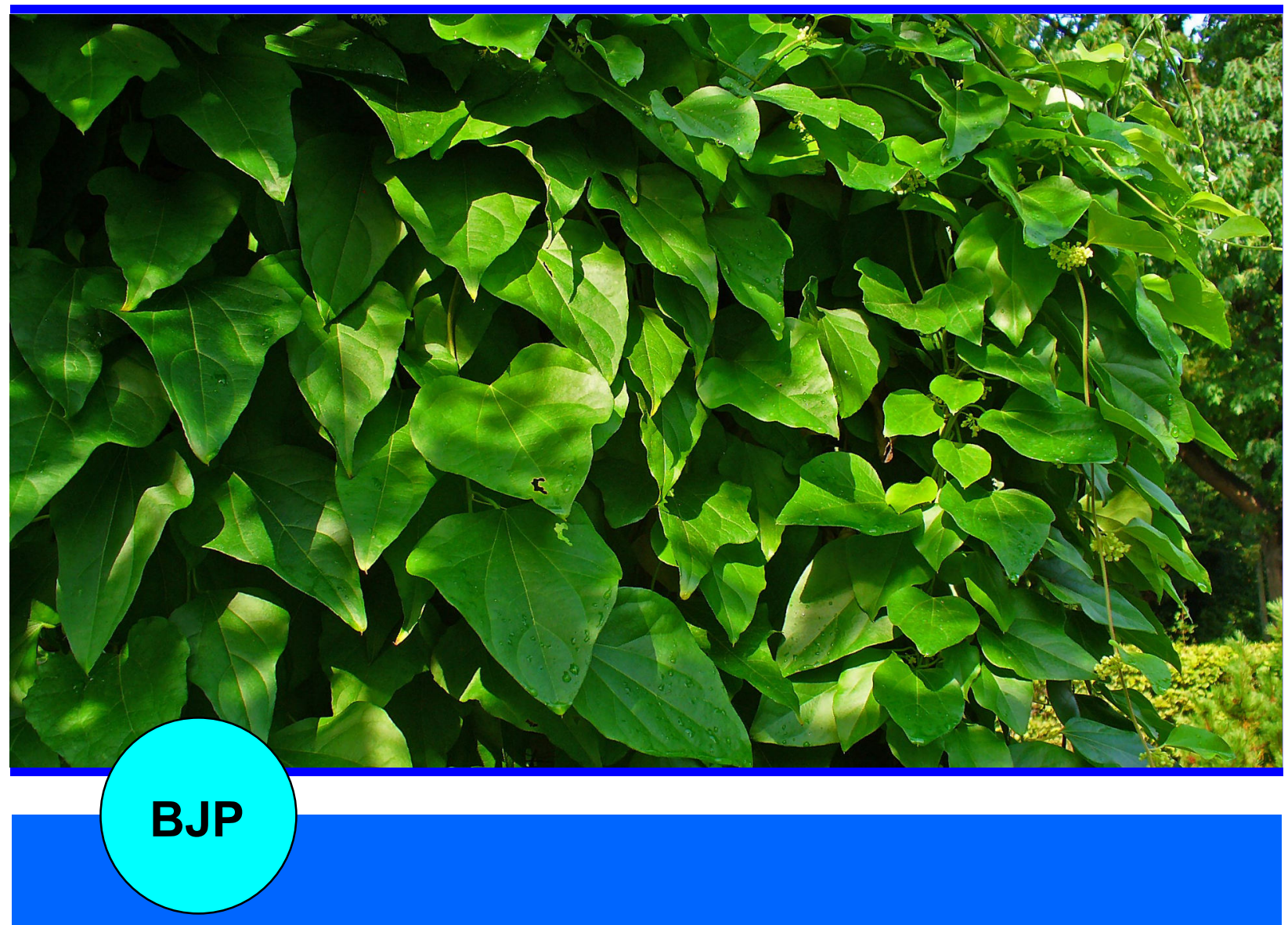

Bangladesh Journal of Pharmacology

Research Article

Evaluation of possible mechanisms of three plants for blood glucose control in diabetes 
Abstracted/indexed in Academic Search Complete, Asia Journals Online, Bangladesh Journals Online, Biological Abstracts, BIOSIS Previews, CAB Abstracts, Current Abstracts, Directory of Open Access Journals, EMBASE/Excerpta Medica, Google Scholar, HINARI (WHO), International Pharmaceutical Abstracts, Open J-gate, Science Citation Index Expanded, SCOPUS and Social Sciences Citation Index;

ISSN: $1991-0088$

\section{Evaluation of possible mechanisms of three plants for blood glucose control in diabetes}

\section{Damayanthi Dalu ${ }^{1}$ and Satyavati Dhulipala ${ }^{2}$}

${ }^{1}$ Department of Pharmacology, Netaji Institute of Pharmaceutical Science, Toopranpet, Choutuppal, Nalgonda 508 252, Telangana, India; ' Satyavati Dhulipala, Department of Pharmacology, Brilliant College of Pharmacy, Abdullapurmet, Hayatnagar, Ranga Reddy, Hyderabad 501 505, Telangana, India.

\begin{tabular}{|c|c|}
\hline \multicolumn{2}{|l|}{ Article Info } \\
\hline $\begin{array}{l}\text { Received: } \\
\text { Accepted: } \\
\text { Available Online: }\end{array}$ & $\begin{array}{r}8 \text { September } 2015 \\
8 \text { November } 2015 \\
24 \text { January } 2016\end{array}$ \\
\hline \multicolumn{2}{|c|}{ DOI: 10.3329/bjp.v11i1.24932 } \\
\hline \multicolumn{2}{|c|}{$\begin{array}{l}\text { Cite this article: } \\
\text { Dalu D, Dhulipala S. Evaluation of } \\
\text { possible mechanisms of three plants } \\
\text { for blood glucose control in diabetes. } \\
\text { Bangladesh J Pharmacol. 2016; 11: } 224 \\
-30 \text {. }\end{array}$} \\
\hline
\end{tabular}

\begin{abstract}
This study was conducted to provide the evidence for the mechanism of antidiabetic activity of Cocculus orbiculatus, Leea indica and Ventilago maderaspatana. This was accomplished by employing methods like uptake of glucose, glycogen synthesis and inhibition of a-glucosidase. For uptake of glucose, diaphragms were dissected out in Tyrode solution with $2 \%$ glucose and assayed for glucose content. In glycogen synthesis methodology liver, skeletal muscle and cardiac muscles were isolated, homogenized and glycogen content was analyzed. In a-glucosidase enzyme inhibition procedure involved estimation of a-glucosidase enzyme inhibition. All the three plant extracts exhibited significant $(p<0.05-p<0.01)$ anti-diabetic activity by increasing glucose uptake, glycogen synthesis and inhibiting a-glucosidase enzyme. Among the three plants, V. maderaspatana $(500 \mathrm{mg} / \mathrm{kg})$ exhibited higher glucose uptake, glycogen content and a-glucosidase inhibition activity $\left(\mathrm{IC}_{50}\right.$ $145 \mu \mathrm{g} / \mathrm{mL}$ ). The present experimental results evidenced the anti-diabetic activity of three plants by all the three mechanisms.
\end{abstract}

\section{Introduction}

Diabetes mellitus is characterized by impaired production of insulin and/or diminished stimulation of insulin sensitive peripheral tissues associated with a marked decrease in glucose uptake and metabolism in response to insulin. The defective glucose transport system plays a significant role in the pathogenesis of peripheral insulin resistance. Glucose uptake in target tissues is a crucial step in maintaining glucose homeostasis and in lowering the postprandial glucose load (Shulman, 2000). Direct stimulation of glucose transport and metabolism in muscle and fat cells lead to enhanced glucose utilization. To attenuate the glucose uptake by peripheral cells, biguanides are employed. Cellular assays are utilized to investigate the mechanism of action of natural compounds using isolated rat diaphragms. It is highly preferred to explore modern anti-diabetic agents from natural sources that stimulate glucose uptake/ disposal by peripheral tissues such as adipose tissue or muscle cells.

The pivotal enzyme for carbohydrate digestion is aglucosidase. This is a therapeutic target for the modulation of postprandial hyperglycemia, the earliest abnormality that occurs in NIDDM (Kim et al., 2005). Dietary carbohydrates are the major source for blood glucose. These carbohydrates are hydrolyzed by a-glucosidase, so as to be absorbed by small intestine. Therefore, the most effective treatment is to inhibit the activity of aglucosidase (Krentz and Bailey, 2005). a-Glucosidase inhibitors such as acarbose, miglitol and voglibose reduce postprandial hyperglycemia by inhibiting the activity of carbohydrate digesting enzymes and delaying glucose absorption.

Previously, we have reported anti-diabetic, anti-hyperlipidemic and anti-oxidant activity of three medicinal 
plants Cocculus orbiculatus, Leea indica and Ventilago maderaspatana in the treatment of diabetes (Damayanthi and Satyavati, 2015; Damayanthi et al., 2014; Damayanthi and Satyavati, 2015). But, till date there are no scientific evaluation reports available to support the mechanisms responsible for anti-diabetic activity. Therefore, the present investigation was aimed to ascertain in vivo anti-diabetic activity by methods such as glucose uptake activity using isolated rat diaphragm and glycogen synthesis in liver, skeletal muscle and cardiac muscle and in vitro anti-diabetic activity by inhibiting a-glucosidase enzyme.

\section{Materials and Methods}

\section{Plant materials}

Aerial parts of C. orbiculatus were collected from Tirumala forest area, Tirupathi. L. indica leaves were procured from Karthikavanam forest area, Dhulapally, Hyderabad. V. maderaspatana roots were obtained from Tirumala forest area, Tirupathi. The plants were authenticated by Prof. Madhava Chetty, Department of Botany, Sri Venkateshwara University, Tirupathi, India.

\section{Chemicals}

Streptozotocin was procured from Sigma-Aldrich. Glucose estimation kit was obtained from Erba Diagnostics, Mannheim. Glibenclamide (Oglucon) was purchased from Alpha pharmaceuticals, Apollo pharmacy, Bathala -palli, Ananthapur. Insulin (Novo Nordisk) was obtained from Alpha pharmaceuticals, Bathalapalli, Ananthapur. Glucose was purchased from Sd Fine Chemicals, India.

\section{Preparation of plant extract}

Aerial parts of C. orbiculatus were finely powedered, packed in soxhlet apparatus and then extracted with hydroalcohol (60:40). Leaves of L. indica were air dried at room temperature, coarsely powdered extracted by maceration with hydroalcohol (3:1). $V$. maderaspatana roots were finely powered and extracted by using soxhlet apparatus with hydroalcohol solvent (60:40). Percentage yield of the plants C. orbiculatus, L. indica, $V$. maderaspatana was found to be 16.7, 25.6 and $15.8 \%$ respectively.

\section{Preliminary phytochemical analysis}

All the three plant extracts were subjected to prelimnary phytochemical analysis to determine the phytoconstituents employing standard tests (Harbone, 1998).

\section{Animals}

Wistar albino rats weighing about 200-250 g were procured from Raghavendra enterprises, Banglore. The animals were acclimatized (2 weeks); housed under standard laboratory conditions (temperature $23 \pm 2^{\circ} \mathrm{C}$ ), humidity $55-70 \%$ and fed with commercial diet Durga feeds, Bangalore.

\section{a-glucosidase inhibitory assay}

This assay was assigned to investigate the in vitro inhibitory activity of three plant extracts on a-glucosidase enzyme. a-Glucosidase $(100 \mu \mathrm{L}$ of $1 \mathrm{U} / \mathrm{mL})$ was mixed with phosphate buffer $(100 \mu \mathrm{L}, \mathrm{pH} 7.0)$ containing 100 $\mu \mathrm{L}$ of three plant extracts $(25-1600 \mu \mathrm{L})$ or standard drug acarbose $(0.1-3.2 \mu \mathrm{g} / \mathrm{mL})$. This mixture is incubated at $37^{\circ} \mathrm{C}$ for $60 \mathrm{~min}$ in maltose solution. Later the mixture is kept in boiling water for 2 min and cooled. The boiling stops the a-glucosidase action on maltose. Glucose reagent $(2 \mathrm{~mL})$ was added and absorbance is measured at $540 \mathrm{~nm}$ to estimate the amount of liberated glucose by the action of a-glucosidase (Kuppusamy et al., 2011)

Glucose uptake in normal and streptozotocin-induced diabetic rats

The glucose uptake using rat hemidiaphragm was estimated according to the method reported elsewhere (Walass and Walass, 1952; Chattopadhyay et al., 1992), but with some modifications. After 18 hours fasting; rats were killed by decapitation. Diaphragms were dissected out quickly with minimal trauma and divided into two halves. Hemidiaphragms were then rinsed in cold Tyrode solution (without glucose) to remove blood clots. Then these were weighed and placed in test tubes. The volumes in all test tubes were made equal by adding distilled water. The test tubes were incubated for $30 \mathrm{~min}$ at $37^{\circ} \mathrm{C}$ in an atmosphere of $100 \%$ oxygen and were shaken at 140 cycles/min. Hemidiaphragms were taken out. Glucose content of the incubated medium before and after incubation was measured. This was carried out by employing Erba Diagnostic Mannheim kit using GOD-POD method (Barham and Trinder, 1972) and Erba Mannheim Chem-7 semiautoanalyzer. Glucose uptake was calculated as the difference between initial and final glucose content. Glucose uptake was expressed as $\mathrm{mg} / \mathrm{g}$ of tissue per 30 min of incubation. Rats were divided into 12 groups; six in normal group and six in diabetic control group of five rats each. In normal group: Group I (normal rats; received $2 \mathrm{~mL}$ Tyrode solution with $2 \%$ glucose); Group II (received Tyrode solution and $0.6 \mathrm{~mL}$ of $0.4 \mathrm{IU} / \mathrm{mL}$ insulin); Group III (administered Tyrode solution and standard drug, metformin- $2 \mathrm{~mL}$ of $0.1 \%$ ); Group IV (received Tyrode solution and $300 \mathrm{mg} / \mathrm{kg}$ of $C$. orbiculatus); Group V (received Tyrode solution$400 \mathrm{mg} / \mathrm{kg}$ of L. indica); Group VI (administered Tyrode solution and $500 \mathrm{mg} / \mathrm{kg} \mathrm{V}$. maderaspatana).

In diabetic control group: Group VII (diabetic control group, untreated); Group VIII (received Tyrode solution and $0.6 \mathrm{~mL}$ of $0.4 \mathrm{IU} / \mathrm{mL}$ insulin); Group IX (administered Tyrode solution and standard drug, metformin- $2 \mathrm{~mL}$ of $0.1 \%$ ); Group X (received Tyrode solution and $300 \mathrm{mg} / \mathrm{kg} \quad$ C. orbiculatus); 
Group XI (received Tyrode solution and $400 \mathrm{mg} / \mathrm{kg} L$. indica); Group XII (administered Tyrode solution and 50 $0 \mathrm{mg} / \mathrm{kg} V$. maderaspatana)

\section{Glycogen estimation in normal and streptozotocin- induced diabetic rats}

The glycogen content in liver, skeletal muscle and cardiac muscle was estimated by Carroll et al., (1956). Rats were divided into ten groups: Five in normal group and five in diabetic control group of five rats each.

Normal group: Group I (normal rats; received 1\% sodium carboxymethyl cellulose); Group II (received standard drug, glibenclamide $10 \mathrm{mg} / \mathrm{kg}$ ); Group III (administered $300 \mathrm{mg} / \mathrm{kg}$ of C. orbiculatus); Group IV (administered $400 \mathrm{mg} / \mathrm{kg}$ of L. indica) Group V (administered $500 \mathrm{mg} / \mathrm{kg}$ V. maderaspatana)

Diabetic control group: Group VI (diabetic control group, untreated); Group VII (diabetic control received standard drug, glibenclamide $10 \mathrm{mg} /$ $\mathrm{kg}$ ); Group III (diabetic control administered $300 \mathrm{mg} /$ $\mathrm{kg}$ of C. orbiculatus); Group IV (diabetic control administered $400 \mathrm{mg} / \mathrm{kg}$ of L. indica); Group V (diabetic control administered $500 \mathrm{mg} / \mathrm{kg}$ of $V$. maderaspatana)

After 18 hours of fasting, plant extracts were administered to different groups. Two hours later they were sacrificed by decapitation. The liver, skeletal muscle and cardiac muscle were isolated, weighed and homogenized using $10 \mathrm{~mL}$ of $4 \%$ trichloroacetic acid and centrifuged for $10 \mathrm{~min}$. Supernatant was decanted and precipitate is discarded. To $2 \mathrm{~mL}$ of supernatant $4 \mathrm{~mL}$ of anthrone reagent was added. Later test tubes were allowed to cool for $30 \mathrm{~min}$. Absorbance was measured at $620 \mathrm{~nm}$ using spectrophotometer. Glycogen content was expressed as milligram for $100 \mathrm{~g}$ of tissue.

Glycogen content $=\mathrm{DU} \times 0.2 \times$ volume of the extract $\mathrm{x}$ 1000 DS $x$ weight of the tissue

$\mathrm{DU}=$ Absorbance of the sample; $\mathrm{DS}=$ Absorbance of the standard

\section{Statistical analysis}

The experimental results were presented as mean \pm standard error mean (SEM). Statistical analysis was performed by graphpad instat version 3.2. Probability value of analysis $p<0.01$ and $p<0.05$ was considered to be statistically significant.

\section{Results}

\section{Preliminary phytochemical analysis}

Phytochemical analysis of C. orbiculatus exhibited positive results for alkaloids, glycosides, carbohydrates, flavonoids, saponins, tannins, terpenoids, polyphenols and starches (Table I). Phytochemical analysis of $L$. indica exhibited the presence of alkaloids, terpenoids, carbohydrates, flavonoids, tannins and saponins. Preliminary phytochemical analysis of $V$. maderaspatana revealed the presence of alkaloids, glycosides, emodin, cardiac glycosides, carbohydrates, flavonoids, tannins and saponins. The constituents like aporphine

Table I

Phytochemical screening of $C$. orbiculatus, L. indica and V. maderaspatana

\begin{tabular}{lccc|}
\hline Phytoconstituents & C. orbiculatus & L. indica & V. maderaspatana \\
\hline Alkaloids & ++ & ++ & ++ \\
Glycosides & ++ & -- & ++ \\
Carbohydrates & ++ & ++ & ++ \\
Terpenoids & ++ & ++ & ++ \\
Flavonoids & ++ & ++ & ++ \\
Saponins & ++ & ++ & ++ \\
Tannins & ++ & -- & -- \\
Starches & ++ & -- & -- \\
Polyphenols & ++ & ++ & - \\
Steroids & -- & ++ & -- \\
Gallic acid & -- & ++ & ++ \\
$\beta-$ Sitosterol & -- & ++ & ++ \\
Cardiac glycosides & -- & -- & ++ \\
Emodin & -- & -- & ++ \\
Dam-karrer test & -- & -- & + \\
Juglone test & -- & ++ & + \\
\hline
\end{tabular}

Note: Present (++); Absent (--) 
Table II

Effect of C. orbiculatus, L. indica and V. maderaspatana on inhibiton of a-glucosidase enzyme

\begin{tabular}{|c|c|c|c|}
\hline Treatment & Concentration $(\mu \mathrm{g} / \mathrm{mL})$ & $\%$ Inhibition & $\mathrm{IC}_{50}(\mu \mathrm{g} / \mathrm{mL})$ \\
\hline \multirow[t]{7}{*}{ C.orbiculatus } & 25 & $8.3 \pm 0.5$ & \multirow[t]{7}{*}{325.1} \\
\hline & 50 & $17.1 \pm 0.5$ & \\
\hline & 100 & $23.2 \pm 0.4$ & \\
\hline & 200 & $37.1 \pm 0.5$ & \\
\hline & 400 & $55.3 \pm 1.7$ & \\
\hline & 800 & $67.3 \pm 1.2$ & \\
\hline & 1000 & $85.7 \pm 1.4$ & \\
\hline \multirow[t]{7}{*}{ L. indica } & 25 & $10.3 \pm 0.4$ & \multirow[t]{7}{*}{265.3} \\
\hline & 50 & $20.5 \pm 0.7$ & \\
\hline & 100 & $33.7 \pm 0.5$ & \\
\hline & 200 & $45.3 \pm 0.8$ & \\
\hline & 400 & $62.2 \pm 0.9$ & \\
\hline & 800 & $79.5 \pm 1.3$ & \\
\hline & 1000 & $90.3 \pm 1.8$ & \\
\hline \multirow[t]{7}{*}{ V. maderaspatana } & 25 & $15.1 \pm 0.3$ & \multirow[t]{7}{*}{145.0} \\
\hline & 50 & $29.3 \pm 0.4$ & \\
\hline & 100 & $43.7 \pm 0.7$ & \\
\hline & 200 & $56.3 \pm 0.5$ & \\
\hline & 400 & $75.3 \pm 1.0$ & \\
\hline & 800 & $88.9 \pm 1.1$ & \\
\hline & 1000 & $95.8 \pm 1.3$ & \\
\hline \multirow[t]{6}{*}{ Acarbose } & 0.1 & $30.7 \pm 0.4$ & \multirow[t]{6}{*}{0.2} \\
\hline & 0.2 & $47.3 \pm 0.7$ & \\
\hline & 0.4 & $59.2 \pm 1.1$ & \\
\hline & 0.8 & $73.1 \pm 2.1$ & \\
\hline & 1.6 & $81.2 \pm 1.9$ & \\
\hline & 3.2 & $96.2 \pm 1.7$ & \\
\hline
\end{tabular}

and berberine, ursolic acid, gallic acid, $\beta$-sitosterol, emodin and physcion were found by the analysis of $C$. orbiculatus, L. india and V. maderaspatana.

\section{a-Glucosidase inhibitory activity}

C. orbiculatus, L. india and V. maderaspatana hydroalcoholic extracts exhibited 8.3, 10.3 and 15.1\% inhibition of a-glucosidase activity at $25 \mu \mathrm{g} / \mathrm{mL}$ and 85.7, 90.3 and $95.8 \%$ inhibition at $1000 \mu \mathrm{g} / \mathrm{mL}$ respectively (Table II). The $\mathrm{IC}_{50}$ values were 325, 265 and $145 \mu \mathrm{g} / \mathrm{mL}$. IC 50 value of acarbose was found to be $0.2 \mu \mathrm{g} / \mathrm{mL}$.

\section{Effect on peripheral glucose uptake}

Table III show glucose uptake in an isolated rat hemidiaphragm muscle of normal and diabetic animals. Addition of C. orbiculatus, L. india and V. maderaspatana hydroalcoholic extracts elicited significant increase in glucose uptake by the rat hemidiaphragm in normal animals. $V$. maderaspatana seemed to be more effective in enhancing peripheral glucose uptake than L. indica, C. orbiculatus and metformin. The glucose uptake by rat hemidiaphragm was significantly higher in all the groups when compared to control group. Diabetic control animals exhibited significant increase in glucose uptake of C. orbiculatus, L. india and V. maderaspatana (37.7, 40.8 and $48.0 \%$ respectively). Glucose uptake of $V$. maderaspatana was significantly higher when compared to L. india and C. orbiculatus

Effect on glycogen content in liver, skeletal muscle and cardiac muscle in normal animals

Hydroalcoholic extracts of C. orbiculatus, L. india and V. maderaspatana showed significantly increased glycogen content in liver (Table IV). Increase in glycogen content was more for $V$. maderaspatana than L. india, $C$. orbiculatus and glibenclamide. Skeletal muscle glycogen content was increased more for all the three plant extracts. Increase was greater for $V$. maderaspatana than L. india, C. orbiculatus and glibenclamide. Significant 


\begin{tabular}{|c|c|c|c|}
\hline \multicolumn{4}{|c|}{ Table III } \\
\hline \multicolumn{4}{|c|}{$\begin{array}{l}\text { Effect of C. orbiculatus, } L . \text { indica and V. maderaspatana on glucose uptake in isolated rat hemidiaphragm } \\
(\mathrm{mg} / \mathrm{g} / 30 \mathrm{~min})\end{array}$} \\
\hline Group & Treatment $(\mathrm{mg} / \mathrm{kg})$ & Glucose uptake in normal rats & Glucose uptake in diabetic rats \\
\hline I & Normal & $5.4 \pm 0.15$ & $4.7 \pm 0.2$ \\
\hline II & Insulin (0.4 IU) & $\begin{array}{r}12.7 \pm 0.6^{\mathrm{b}} \\
(57.5 \%)\end{array}$ & $\begin{array}{r}11.5 \pm 0.8^{\mathrm{b} \backslash} \\
(59.2 \%)\end{array}$ \\
\hline III & Metformin $(0.1 \%)$ & $\begin{array}{r}9.6 \pm 0.2^{\mathrm{b}} \\
(43.5 \%)\end{array}$ & $\begin{array}{r}8.3 \pm 0.9^{\mathrm{b}} \\
(43.6 \%)\end{array}$ \\
\hline IV & C. orbiculatus (300) & $\begin{array}{r}8.4 \pm 0.3^{b} \\
(35.7 \%)\end{array}$ & $\begin{array}{l}7.5 \pm 0.4^{\mathrm{b}} \\
(37.7 \%)\end{array}$ \\
\hline $\mathrm{V}$ & L. indica $(400)$ & $\begin{array}{r}9.1 \pm 0.5^{\mathrm{b}} \\
(40.7 \%)\end{array}$ & $\begin{array}{l}7.9 \pm 0.2^{\mathrm{b}} \\
(40.8 \%)\end{array}$ \\
\hline VI & V. maderaspatana $(500)$ & $\begin{array}{r}11.3 \pm 0.7^{\mathrm{b}} \\
(52.4 \%)\end{array}$ & $\begin{array}{c}9.0 \pm 0.1^{\mathrm{b}} \\
(48.0 \%)\end{array}$ \\
\hline
\end{tabular}

IU: International units; Mean \pm SEM; $\mathrm{n}=5$; Groups II - VI were compared with Group I. $\mathrm{b}(\mathrm{p}<0.01)$

\section{Table IV}

Effect of C. orbiculatus, L. indica and V. maderaspatana on glycogen content in liver, skeletal muscle and cardiac muscle (mg/100 g)

\begin{tabular}{|clc|c|c|c|c|c|}
\hline Group & Treatment & \multicolumn{2}{c}{ Glycogen concentration in normal rats } & \multicolumn{3}{c|}{ Glycogen concentration in diabetic rats } \\
\cline { 3 - 8 } & & Liver & $\begin{array}{c}\text { Skeletal mus- } \\
\text { cle }\end{array}$ & $\begin{array}{c}\text { Cardiac mus- } \\
\text { cle }\end{array}$ & Liver & $\begin{array}{c}\text { Skeletal mus- } \\
\text { cle }\end{array}$ & $\begin{array}{c}\text { Cardiac mus- } \\
\text { cle }\end{array}$ \\
I & Normal & $136.5 \pm 2.3$ & $30 \pm 1.2$ & $29 \pm 1.4$ & $116 \pm 1.2$ & $22 \pm 1.4$ & $21 \pm 1.0^{2}$ \\
II & Glibenclamide (10) & $153.0 \pm 2.0^{\mathrm{b}}$ & $39.5 \pm 0.8^{\mathrm{b}}$ & $40.5 \pm 1.3^{\mathrm{b}}$ & $143 \pm 1.0^{\mathrm{b}}$ & $33.7 \pm 0.6^{\mathrm{b}}$ & $37 \pm 0.7^{\mathrm{b}}$ \\
III & C. orbiculatus (300) & $142.2 \pm 2.0^{\mathrm{a}}$ & $35 \pm 1.1^{\mathrm{a}}$ & $32.7 \pm 0.4^{\mathrm{a}}$ & $126 \pm 0.8^{\mathrm{b}}$ & $26 \pm 0.8^{\mathrm{a}}$ & $26 \pm 0.7^{\mathrm{b}}$ \\
IV & L. indica (400) & $150.7 \pm 2.0^{\mathrm{b}}$ & $38 \pm 1.9^{\mathrm{b}}$ & $33.7 \pm 0.6^{\mathrm{b}}$ & $131.3 \pm 0.9^{\mathrm{b}}$ & $30 \pm 0.8^{\mathrm{b}}$ & $33 \pm 1.1^{\mathrm{b}}$ \\
V & V. maderaspatana (500) & $162.5 \pm 2.9^{\mathrm{b}}$ & $40 \pm 0.9^{\mathrm{b}}$ & $41.0 \pm 0.7^{\mathrm{b}}$ & $139 \pm 1.0^{\mathrm{b}}$ & $32.7 \pm 1.0^{\mathrm{b}}$ & $36.7 \pm 1.3^{\mathrm{b}}$ \\
\hline
\end{tabular}

Mean \pm SEM; $\mathrm{n}=5$; Groups II - VI were compared with Group I. ${ }^{\mathrm{a}}(\mathrm{p}<0.05) ;{ }^{\mathrm{b}}(\mathrm{p}<0.01)$

increase in cardiac muscle glycogen content was observed for $V$. maderaspatana than $L$. india and $C$. orbiculatus. $V$. maderaspatana exhibited increased cardiac muscle glycogen content than L. india, C. orbiculatus and glibenclamide.

Effect on glycogen content in liver, skeletal muscle and cardiac muscle in diabetic animals

Three plants have elicited significantly increased liver glycogen content. V. maderaspatana manifested higher liver glycogen content than L. indica and C. orbiculatus. Significantly increased skeletal muscle glycogen content was observed for $V$. maderaspatana $L$. indica and $C$. orbiculatus. Glycogen content was more in $V$. maderaspatana than L. indica and C. orbiculatus . Cardiac muscle glycogen content increase was observed for all the three plants. Among these $V$. maderaspatana exhibited increased glycogen content than L. indica and C. orbiculatus.

\section{Discussion}

In current study, we investigated the mechanism for anti-diabetic activity of three plants (C. orbiculatus, L. and $V$. maderaspatana) by employing glucose uptake, glycogen synthesis and a-glucosidase enzyme inhibition methods. Three plants showed significant uptake of glucose and are more or less effective than insulin. V. maderaspatana has evidenced greater uptake of glucose than L. india, C. orbiculatus, metformin and comparatively equal to insulin. Glibenclamide showed increased glycogen content in muscle cells. Therapy with the three plants evidenced increased glucose uptake and thereby glycogen storage in liver, skeletal muscle and cardiac muscle. V. maderaspatana increased glycogen content greater than L. india and C. orbiculatus. The three plants also evidenced a-glucosidase inhibitory activity among which $V$. maderaspatana exhibited greater activity.

The impaired glucose uptake is linked with decrease in the translocation of glut 4 and is the major cause of insulin resistance. Metformin and insulin stimulate glucose uptake in muscle cells by increasing GLUT 4 (Klip and Leiter, 1990). Berberine the reported active constituent of $C$. orbiculatus has been investigated to activate AMPK in skeletal muscle and adipose tissue that lead to increased glucose uptake (Yin et al., 2008; Cheng et al., 2006; Kim et al., 2007; Lee et al., 2006; Zhou et al., 2007; 
Wang et al., 2004; Ko et al., 2005). Similarly gallic acid the constituent of L. india has been implicated to mediate insulin stimulated glucose transport in muscle and adipocytes (Vishnu Prasad et al., 2010). Finally VMHAE possess emodin that mediated Glut 1 and Glut 4 expression to enhance glucose uptake in skeletal muscles and adipocytes (Yang et al., 2007). Glibenclamide increased glycogen content in muscle but adverse effects like hypoglycemia and weight gain limits the use. Hence drugs that attenuate glycogen content without adverse effects were desirable for long term anti-diabetic therapy. The three plants evidenced enhanced glucose uptake and glycogen storage in liver, skeletal muscle and cardiac muscle. The increased glycogen levels by the three plants might be due to the berberine of $C$. orbiculatus that evidenced glucose utilization in Hep $\mathrm{G}_{2}$ cells and 3T3-L1 adipocytes increasing glycogen content (Yin J et al., 2002; Zhou et al., 2003; Zhou et al., 2003). Gallic acid, the constituent of L. india by insulin secretagogue action produced increased glycogen levels (Punithavathi et al., 2011). Emodin of $V$. maderaspatana, the natural PPARY activator, up-regulated PPAR $\gamma$ and increased glycogen content (Yonemitsu et al., 2001). Acarbose, the aglucosidase inhibitor has common side effects (flatulence and abdominal bloating). Herbal drugs devoid of side effects are desired to improve compliance for diabetic patients. The constituents like berberine, $\beta$-sitosterol and emodin of the plants have reported a-glucosidase inhibitory activity (Pan et al., 2003; Sunil Kumar et al., 2013; Yang et al., 2014). Thus active constituents of the experimental study might be responsible for the elicited a-glucosidase inhibitory activity of C. orbiculatus, L. indica and V. maderaspatana .

\section{Conclusion}

The experimental reports evidenced C. orbiculatus, L. indica and $V$. maderaspatana plants act through multiple mechanisms like increased glucose uptake, glycogen synthesis in muscle cells and a-glucosidase inhibition to control blood glucose in diabetes. $V$. maderaspatana elicited higher antidiabetic activity compared to $L$. indica and C. orbiculatus.

\section{Ethical Issue}

Experiments were conducted in accordance with the guidelines of CPCSEA REGD N0: 878/ac/05/ CPCSEA/21/2015. The study protocol was approved by Institutional Animal ethics committee.

\section{Conflict of Interest}

The authors declare they have no financial conflict of interest.

\section{Acknowledgement}

The authors express deep gratitude to N. Raja Kumar, Y. Ganesh Kumar and S. Nagarjuna whose valuable contributions lead to successful completion of the work. The authors also thank the College Raghavendra Institute of Pharmaceutical Education and Research for providing necessary facilities.

\section{References}

Barham D, Trinder P. An improved colour reagent for the determination of blood glucose by the oxidase system. Analyst 1972. 97: 142-45.

Carroll NV, Longely RW, Rose JH. The determination of glycogen in liver and muscle by use of anthrone reagent. J Biol Chem. 1956; 220: 583-93.

Chattopadhyay RR, Sarkar SK, Ganguly S, Banerjee RN, Basu TK. Effect of leaves of Vinca rosea Linn. on glucose utilization and glycogen deposition by isolated rat hemidiaphragm. Indian J Physiol Pharmacol. 1992; 36: 137-38.

Cheng Z, Pang T, Gu M, Gao AH, Xie CM, Li JY, Nan FJ, Li J. Berberine-stimulated glucose uptake in L6 myotubes involves both AMPK and p38 MAPK. Biochim Biophys Acta. 2006; 1760: 1682-89.

Damayanthi D, Satyavati D, Suresh A. Antihyperglycemic and hypolipidemic activity of Leea indica. Int J Bioassays. 2014; 3: 3155-59.

Damayanthi D, Satyavati D. Anti-diabetic and antihyperlipidemic activity of alcoholic and hydroalcoholic extracts of Cocculus orbiculatus in streptozotocin induced diabetic rats. Am J Phytomed Clin Ther. 2015; 3: 276-86.

Damayanthi D, Satyavati D. Anti-diabetic, anti-hyperlipidemic and anti-oxidant properties of roots of Ventilago maderaspatana Gaertn. on streptozotocin-induced diabetic rats. IOSR: J Pharm Biol Sci. 2015; 10: 50-59.

Harbone JB. Phytochemical methods: A guide to modern techniques of plant analysis. $3^{\text {rd }}$ ed. New York, Chapman and Hall Publisher, Springer, 1998, p 302.

Kim YM, Jeong YK, Wang MH, Lee WY, Rhee HI. Inhibitory effect of pine extract on a-glucosidase activity and postprandial hyperglycemia. Nutrition 2005; 21: 756-61.

Kim SH, Shin EJ, Kim ED, Bayaraa T, Frost SC, Hyun CK. Berberine activates GLUT1- mediated glucose uptake in 3T3L1 adipocyte. Biol Pharm Bull. 2007; 30: 2120-25.

Klip A, Leiter L.A. Cellular mechanism of action of metformin. Diabetes Care. 1990; 13: 696-704.

Ko BS, Choi SB, Park SK, jang JS, Kim YE, Park S. Insulin sensitizing and insulinotropic action of berberine from Cortidis rhizome. Biol Pharm Bull. 2005; 28: 1431-37.

Krentz AJ, Bailey CJ. Oral antidiabetic agents: Current role in type 2 diabetes mellitus. Drugs 2005; 65: 385-411.

Kuppusamy A, Muthusamy U, Andichetiar Thirumalaisamy S, Varadharajan S, Ramasamy K, Ramanathan S. In vitro (aglucosidase and a-amylase inhibition) and in vivo antidiabetic property of phytic acid (IP 6) in streptozotocin- 
nicotinamide induced type 2 diabetes mellitus (NIDDM) in rats. J Complement Integrat Med. 2011; 8.

Lee YS, Kim WS, Kim KH, Yoon MJ, Cho HJ, Shen Y, Ye JM, Lee $\mathrm{CH}$, Oh WK, Kim CT. Berberine a natural plant product, activates AMP-activated protein kinase with beneficial metabolic effects in diabetic and insulin-resistant states. Diabetes 2006; 55: 2256-64.

Pan GY, Huang ZJ, Wang GJ, Fawcett JP, Liu XD, Zhao XC, Sun JG, Xie YY. The anti-hyperglycaemic activity of berberine arises from a decrease of glucose absorption. Planta Med. 2003; 69: 632-36.

Punithavathi VR, Stanely Mainzen Prince P, Kumar MR, Selva Kumara CJ. Protective effects of gallic acid on hepatic lipid peroxide metabolism, glycoprotein components and lipids in streptozotocin-induced type II diabetic Wistar rats. J Biochem Molecular Toxic. 2011; 25: 68-76.

Shulman GI. Cellular mechanisms of insulin resistance. J Clin Invest. 2000; 106: 171-76.

Sunil Kumar, Vipin Kumar, Om Prakash. Enzymes inhibition and Anti-diabetic effect of isolated constituents from Dillenia indica. Biomed Res Int. 2013; 2013: 1155-62.

Vishnu Prasad CN, Anjana T, Banerji A, Gopalakrishnapillai A. Gallic acid induces GLUT 4 translocation and glucose uptake activity in 3 T3 cells. FEBS Lett. 2010; 584: 531-36.

Walass E, Walass O. Effect of insulin on rat diaphragm under anaerobic conditions. J Biol Cem. 1952; 195: 367-73.

Wang SH, Wang WJ, Wang XF, Chen W. Effect of Astragalus polysaccharides and berberine on carbohydrate metabolism and cell differentiation in 3T3-L1 adipocytes. Chin J Integr Tradit Chin West Med. 2004; 24: 926-28.
Yang D, Zhao J, Liu S, Song F, Liu ZQ. The screening of potential a-glucosidase inhibitors from the Polygonum multiflorum extract using ultra-filtration combined with liquid chromatography-tandem mass spectrometry. Analyl Methods. 2014; 6: 3353-59.

Yin J, Hu R, Chen M, Tang J, Li F, Yang Y, Chen J. Effects of berberine on glucose metabolism in vitro. Metabolism 2002; 51: $1439-43$.

Yang Y, Shang W, Zhou L, Jiang B, Jin H, Chen M. Emodin with PPARY ligand-binding activity promotes adipocyte differentiation and increases glucose uptake in 3T3-L1 cells. Biochem Biophyl Res Comm. 2007; 353: 225-30.

Yonemitsu S, Nishimura H, Shintani M, Yoshihiro O, Tatsuya $\mathrm{H}$, Kiminori H, Inoue G, Kazuwa N. Troglitazone induces GLUT 4 translocation in L6 myotubes. Diabetes 2001; 50: 1093-101.

Yin J, Gao Z, Liu D, Liu Z, Ye J. Berberine improves glucose metabolism through induction of glycolysis. Am J Physiol Endocrinol Metab. 2008; 294: E148-56.

Zhou LB, Chen MD, Song HD, Yang Y, Wang X, Tang JF, Li FY, Xu MY, Chen JL. Effect of berberine on glucose transport in adipocytes and its mechanism. Chin J Endocrinol Metab. 2003; 19: 479-82.

Zhou LB, Chen MD, Wang X, Song HD, Yang Y, Tang JF, Li FY, Xu MY, Chen JL. Effect of berberine on the differentiation of adipocytes. Zhonghua Yi Xue Za Zhi. 2003; 83: 33840.

Zhou L, Yang Y, Wang X, Liu S, Shang W, Yuan G, Li F, Tang J, Chen M, Chen J. Berberine stimulates glucose transport through a mechanism distinct from insulin. Metabolism 2007; 56: 405-12. 


\section{Your feedback about this paper}

1. Number of times you have read this paper 0

2. Quality of paper Click

3. Your comments

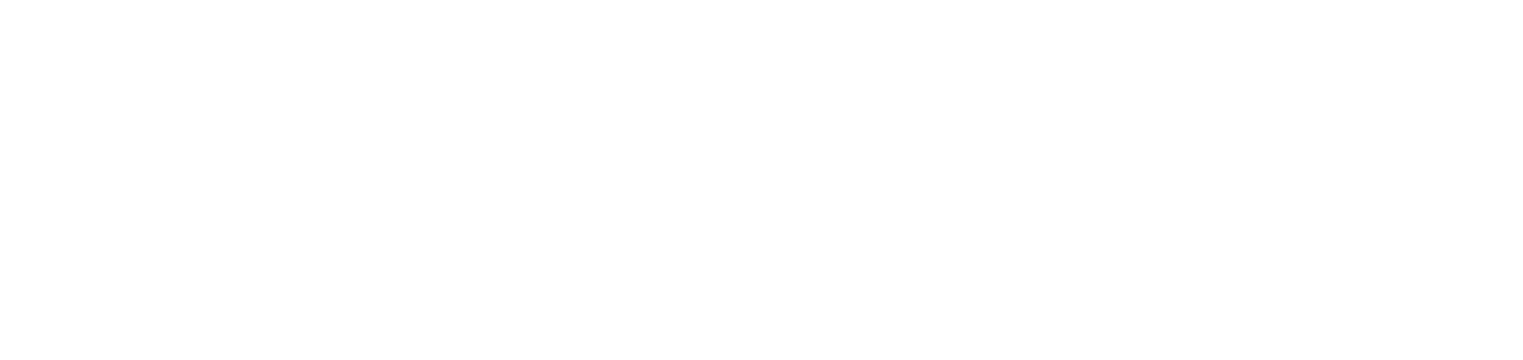

